\title{
Importance of aerobiological monitoring to determine artemisia and ambrosia hypersensitivity
}

\author{
Meliha Merve Hiz Çiçekliyurt ${ }^{1}$, Mine Akkaya² \\ 'Faculty of Medicine, Çanakkale Onsekiz Mart University, Çanakkale, Turkey \\ ${ }^{2}$ Department of Medical System Biology, Graduate School of Health Sciences, Çanakkale Onsekiz Mart University, \\ Çanakkale, Turkey
}

\begin{abstract}
Introduction: Allergic sensitization to aeroallergen (atmospheric pollen and fungal spores) is the most common seasonal allergy trigger. The main reason for that study is unexpected skin prick test results obtained in our dermatology department. For that reason, we would like to check whether the consequences depend on cross-reactivity or aeroallergen invasion.

Aim: The purpose of the present study is to determine the pollen types, including the amount and concentration of the native and invasive pollen in the Çanakkale Region during the spring and summer periods. The main reason for that study is unexpected skin prick test results obtained in our dermatology department. For that reason, we would like to check whether the consequences depend on cross-reactivity or aeroallergen invasion. Material and methods: The pollen monitoring station was placed in the Çanakkale Central Public Park. The sampling was performed by a Durham trap based on the gravimetric method. The slide was replaced with a new one every week and evaluated by $10 \times$ ocular and $40 \times$ apochromatic lenses.

Results: The primary pollen producers were the following arboreal plants: Pinus sp. (65.0\%), Quercus sp. (9.37\%), Platanus sp. (4.29\%), Moraceae (3.87\%), Oleaceae (2.71\%). The pollen distribution of herbaceous plants and bushes were determined as Poaceae (4.34\%), Chenopodiaceae (1.99\%), Plantago sp. (1.97\%) and Xanthium sp. (1.35\%). In addition to our current knowledge, Ambrosia pollens' first record was found with a ratio of $0.22 \%$ in the Çanakkale atmosphere. These invasive plants have most probably entered the atmosphere with long-distance transport.

Conclusions: Aerobiological monitoring is essential to determine allergen variety and concentrations to find a cure against pollinosis. The health professionals should apply a skin prick test against a significant allergen, i.e. Ambrosia pollens even if there is no previous report in the region. The authors also advised clinicians to be aware of pollen invasion to ensure that patients do not have false-negative results.
\end{abstract}

\section{KEY WORDS}

allergy, Alien plant, Ambrosia pollinosis, Ailanthus altissima, pollen.

\section{ADDRESS FOR CORRESPONDENCE}

Meliha Merve Hiz Çiçekliyurt PhD, Faculty of Medicine, Çanakkale Onsekiz Mart University, Çanakkale,

Turkey, phone: +90 5332444545, e-mail: mervemeliha@comu.edu.tr 


\section{INTRODUCTION}

Allergic diseases have become a pandemic health problem. The prevalence of asthma, allergic rhinitis, and atopic dermatitis have increased all over the world. It is estimated that half a billion people suffer from allergic diseases, according to the 2016 statement of the European Academy of Allergy and Clinical Immunology (EAACI) [1]. One hundred fifty million people in Europe suffer from chronic allergic diseases, and the ratio is predicted to reach fifty percent of the entire population by 2025 [1]. Allergic diseases are quite prevalent also in Turkey, and the prevalence varies between $8.5 \%$ and $18 \%$, depending on the environmental and climate differences [2].

Sensitization to an aeroallergen (atmospheric pollen and fungal spores) is the most common seasonal allergy trigger. Pollen triggers urticaria [3], rhinitis, conjunctivitis, and allergic respiratory diseases [4]. The prevalence and severity of pollen allergy are closely related to pollen types, the biology of the plants, and the area's climate $[4,5]$. The standard diagnostic techniques consist of determination of the IgE level in blood and applying skin prick testing [6]. Also, pollen sensitivity causes cross-reactivity against plant origin's food [7-10].

Depending on the factors that affect pollen concentrations and pollens' distribution, the symptoms manifest at different times. Thus, measuring pollen concentration and monitoring yearly fluctuations of allergic pollen exchange is crucial for controlling allergic symptoms.

The Çanakkale Province is located within the boundaries of the Marmara Region with eastern longitude of $25^{\circ} 40^{\prime}-27^{\circ} 30^{\prime}$ and northern latitude of $39^{\circ} 27^{\prime}-40^{\circ} 45^{\prime}$ respectively. The city is the gateways between the Mediterranean and the Black Sea and links Asia and Europe; its climate has features of transitional climate due to the city's location. The pollen distribution changes depending on the city's climatic properties. Together with this, the other species' invasion power on land also relates to the climate properties of cities. The unique climate properties of the town differ from other geographical parts of Turkey.

The main reason for the study is that our hospital's dermatology department has many positive results for pollens that are not native in Çanakkale. Even if there is no similarity of the record between the skin prick test and the city's climate, the increasing number of allergic reactions caused us to evaluate the reason for this positivity. Does the prick test give false positives, or does the pollen distribution change depend on the climate change? In that paper, we would like to evaluate the main reason for increasing pollen allergy results. Does it depend on false-positive signals, or shift in pollen distribution of the atmosphere depends on non-native species' airflow?
AIM

Thus, we aim to examine the pollen types, count, and concentrations derived from biological species and invasive alien species during spring and summer periods with the highest allergenic pollen concentrations in the season in Çanakkale, Turkey.

\section{MATERIAL AND METHODS}

The pollen monitoring station was constructed in the Çanakkale Central Public Park, located in the city centre, and a monitoring study was conducted in April 2019-August 2019 (Figure 1). The aerobiological sampling was performed with a Durham gravimetric sampler, $15 \mathrm{~m}$ above the ground. Samples were prepared according to the Wodehouse method in Guidelines of the European Aerobiology Society Working Group [11]. Slides were renewed weekly, and pollen monitoring was performed by microscope. The identification and quantification of pollens were analysed with a Zeiss Primo Star Light Microscope. The pollen percentages were evaluated. The statistical analyses were performed with SPSS 18.

\section{RESULTS}

The total quantity of pollen was documented as 4513 grains $/ \mathrm{cm}^{2}$ between April and August 2019 at the atmosphere of Çanakkale. In the sampling period, the predominating pollen was from the Pinaceae (65.07\%) families (Figure 2).

The primary pollen producers were the following arboreal plants: Pinus sp. (65.0\%), Quercus sp. (9.37\%), Platanus sp. (4.29\%), Moraceae (3.87\%), Oleaceae (2.71\%). The highest arboreal pollens were Pinus and mostly determined in the $2^{\text {nd }}$ week of April, and the total amount of pollen grains were reached maximum levels in April (Figure 1). The pollen distribution of herbaceous plants and bushes was determined as Poaceae (4.34\%), Chenopodiaceae (1.99\%), Plantago sp. (1.97\%) and Xanthium sp. $(1.35 \%)$. In addition to native species, the pollen of two invasive species with highly allergic structures: $A m$ brosia artemisiifolia and Ailanthus altissima, were found in the Çanakkale atmosphere ratio of $0.22 \%$ and $0.13 \%$, respectively (Figure 3 ). Although Ailanthus altissima is located in the Çanakkale flora, an invasive species, it's surprising to determine Ambrosia artemisiifolia pollen in glass slides. Ambrosia artemisiifolia never reported in Çanakkale land, but invasive plants' pollens have entered our atmosphere with long-distance transport. It's the first record of the Ambrosia artemisiifolia pollen in the Çanakkale atmosphere. Also, there was a significant 



FIGURE 1. The location map of the study area

inverse correlation between the amount of two invasive pollen distribution and the seasons. The highest amount of Ambrosia sp.s pollen was found in August. In contrast, Ailanthus sp. pollen reached its highest level in spring while the lowest level was determined in summer time (Figure 1).

\section{DISCUSSION}

In this study, pollen grains of the invasive plants of local flora brought by airflow were identified and calculated. The aeroallergens in Çanakkale were found as Pinaceae, Quercus sp., Poaceae sp., Platanus sp., Moraceae sp., Oleaceae sp., Chenopodiaceae sp., Plantago sp., Xanthium sp. and Artemisia sp. The pollen grain type and concentrations of pollen are similar to close city pollen calendars.

Ailanthus altissima pollen is a potentially high allergen that causes respiratory disorders [1, 12]. Our data showed that Ailanthus altissima was located in the Çanakkale flora, and pollens occurred in the atmosphere. Also, Ambrosia artemisiifolia pollen was found in the Çanakkale atmosphere for the first time. Ambrosia artemisiifolia is an invasive plant that has a high adapta-

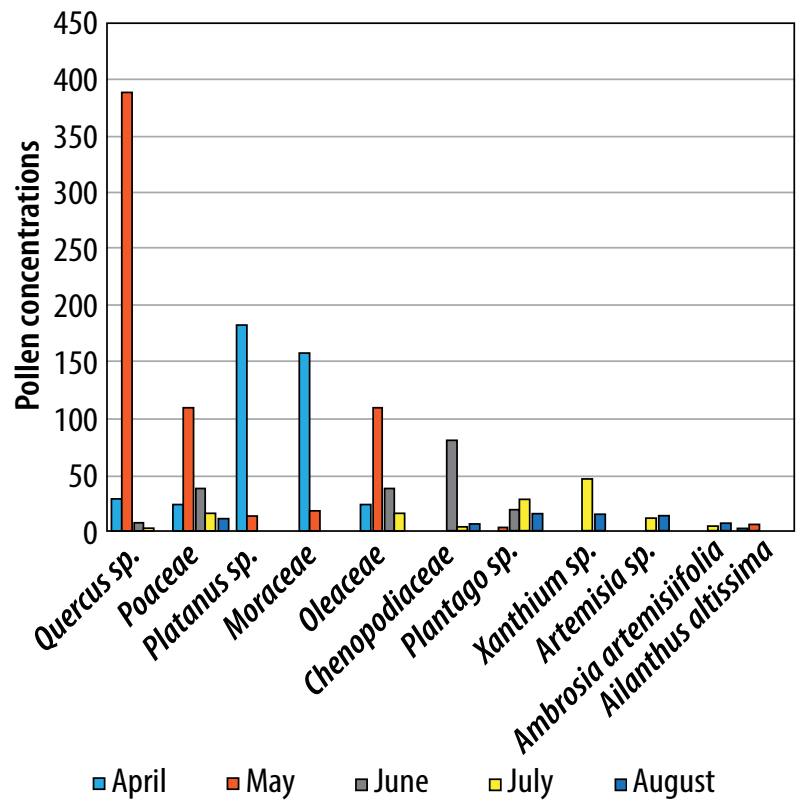

FIGURE 2. Pollen concentrations of the main taxa (pollen grains/ $\mathrm{cm}^{2}$ ) in slides by month

tion ability to many climate and soil conditions. The two different climatic distribution of the ragweed is shown in the Black Sea and Thrace Region. The power of inva- 
A

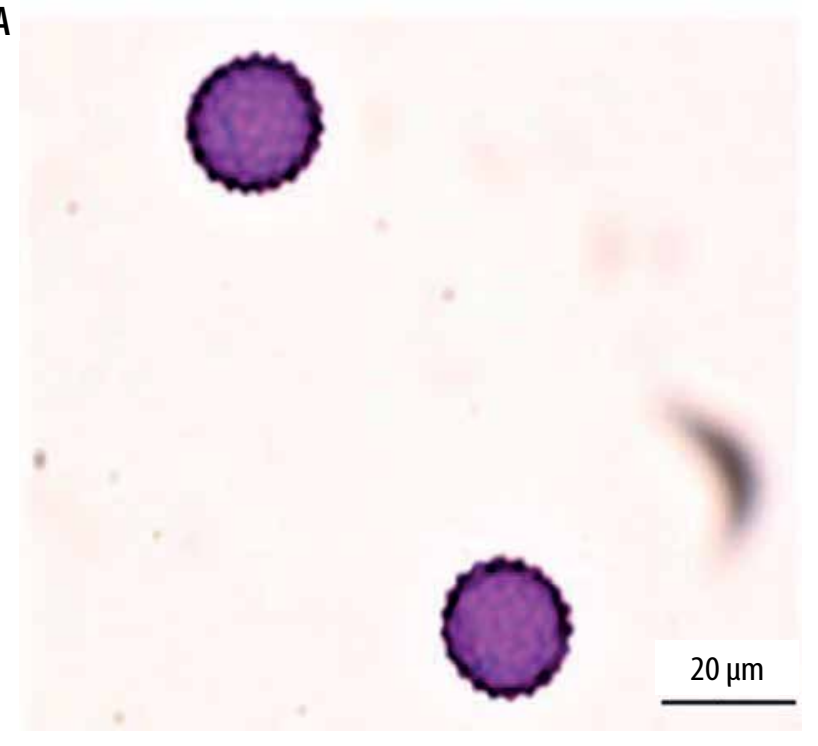

B

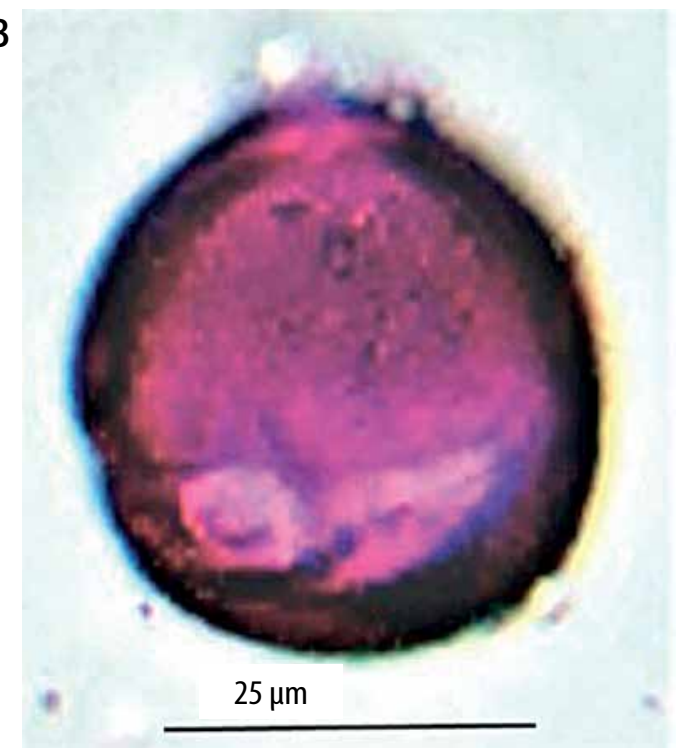

FIGURE 3. Microscopic representation of grains identified in Çanakkale Central: A - Ambrosia artemisiifolia ( $100 \times$ magnification), B - Ailanthus altissima ( $400 \times$ magnification). Microscopy by Mine AKKAYA

sion in a different climate is achieved by different seed germination niche and seedling emergence requirements [13]. Previously, the ragweed (Ambrosia spp.) pollen grains were found in Istanbul and Bursa but not in Kirlareli or Balıkesir [13-15]. The European Commission Cooperation in Science and Technology (COST) Action FA1203 group has prepared a map of the distribution of Ambrosia artemisiifolia in Europe based on the data collected during ten years (2004-2013). According to that COST study, Ambrosia artemisiifolia was shown only in İstanbul and Bursa [16]. Our study's surprising result is the first record of Ambrosia artemisiifolia pollen in the Çanakkale atmosphere.

\section{CONCLUSIONS}

The present findings suggest that health professionals must be aware of Ambrosia artemisiifolia allergy risk in the August-September period even if there are no recorded atmospheric data in their region. In summary, our study has shown the pollen amount and varieties in the Çanakkale region and highlighted two important invasive pollen in the Çanakkale atmosphere. We want to conclude that the results may be useful to predict the beginning of the seasonal pollen allergies and assess the invasive species' impact as triggers of allergic problems. Because allergic diseases arise from many different parameters, comprehensive epidemiological studies examining the correlation of allergic diseases, and the season and allergen exchange should be conducted.

\section{CONFLICT OF INTEREST}

The authors declare no conflict of interest.

\section{REFERENCES}

1. Mondal S, Mondal AK, Mandal S. Evaluation of electroelution and immunodiffusion as methods for purification and identification of the allergenic proteins of Ailanthus excelsa Roxb. pollen. Grana 2007; 46: 91-7.

2. Kurt E, Metintas S, Basyigit I, et al. Prevalence and Risk Factors of Allergies in Turkey (PARFAIT): results of a multicentre cross-sectional study in adults. Eur Respir J 2009; 33: 724-33.

3. Nowicki R, Grubska-Suchanek E, Jahnz-Różyk K, et al. Urticaria. Interdisciplinary diagnostic and therapeutic recommendations of the Polish Dermatological Society and the Polish Society of Allergology. Pol J Allergol 2020; 7: 31-9.

4. Al-Nesf MA, Gharbi D, Mobayed HM, et al. The association between airborne pollen monitoring and sensitization in the hot desert climate. Clin Transl Allergy 2020; 10: 35.

5. Schimit C. Pollen overload: seasonal allergies in a changing climate. Environ Health Perspect 2006; 124: A70-5.

6. Pawliczak R. Skin prick test and patient informed consent. Pol J Allergol 2020; 1: 47-52.

7. Taketomi EA, Sopelete MC, de Sousa Moreira PF, et al. Pollen allergic disease: pollens and its major allergens. Braz J Otorhinolaryngol 2006; 72: 562-7.

8. Popescu FD. Cross-reactivity between aeroallergens and food allergens. World J Methodol 2015; 5: 31-50.

9. Kar Kurt Ö, Erkoçoğlu M, Kurt M. Pollen food allergy syndrome. Tuberk Toraks 2017; 65: 138-45.

10. Bartuzi Z, Lis K, Żbikowska-Gotz M, et al. The role of assay for allergen specific immunoglobulin $\mathrm{G}$ in the diagnosis of food allergy and intolerance. Pol J Allergol 2020; 7: 81-7. 
11. Galán C, Smith M, Thibaudon M, et al. Pollen monitoring: minimum requirements and reproducibility of analysis. Aerobiologia 2014; 30: 385-95.

12. Mousavi F, Majd A, Shahali Y, et al. Immunoproteomics of tree of heaven (Ailanthus atltissima) pollen allergens. J Proteomics 2017; 154: 94-101.

13. Zemmer F, Karaca F, Ozkaragoz F. Ragweed pollen observed in Turkey: detection of sources using back trajectory models. Sci Total Environ 2012; 430: 101-8.

14. Bilisik A, Akyalcin H, Bicakci A. Airborne pollen grains in Savastepe (Balikesir). Ekoloji 2008; 17: 8-14.

15. Erkan P, Bıçakcı A, Aybeke M, et al. Analysis of airborne pollen grains in Kurklareli. Turk J Bot 2011; 35: 57-65.

16. Sikoparija B, Skjøth CA, Celenk S, et al. Spatial and temporal variations in airborne Ambrosia pollen in Europe. Aerobiologia 2017; 33: 181-9. 